\title{
As proposições de Antonio de Saldanha da Gama para a melhoria do tráfico de escravos, "por questões humanitárias e econômicas", Rio de Janeiro, 1810
}

\author{
Antonio de Saldanha da Gama's proposals to improve the slave trade \\ "for humanitarian and economic reasons," Rio de Janeiro, 1810
}

\author{
Ana Carolina de \\ Carvalho Viotti \\ Historiógrafa, Centro de \\ Documentação e Apoio à Pesquisa \\ Histórica/Departamento de \\ História/Universidade Estadual \\ Paulista (Unesp); doutoranda, \\ Programa de Pós-graduação em \\ História/Unesp. \\ Avenida Eufrásia Monteiro \\ Petráglia, 900 \\ 14409-160 - Franca - SP - Brasil \\ anacarolina@franca.unesp.br
}

VIOTTI, Ana Carolina de Carvalho. As proposições de Antonio de Saldanha da Gama para a melhoria do tráfico de escravos, "por questões humanitárias e econômicas", Rio de Janeiro, 1810. História, Ciências, Saúde - Manguinhos, Rio de Janeiro, v.23, n.4, out.-dez. 2016, p.1169-1189.

\section{Resumo}

Em 1808, dom João VI publicou um alvará com força de lei para regular o transporte e o trato dos escravos durante a travessia do Atlântico. Dois anos depois, Antonio de Saldanha da Gama, membro do Conselho da Fazenda, elaborou um ofício para discutir alguns pontos da resolução. Essa importante personagem da administração lusa no Brasil argumentava que suas respeitosas ponderações acerca das determinações da Alteza Real tinham como fim aprimorá-las, "por questões humanitárias e econômicas". Parte do acervo de manuscritos do Arquivo Histórico Ultramarino, de Lisboa, esse ofício se encontra aqui transcrito, comentado e contextualizado, fornecendo interessante visada das preocupações e justificativas daquele tempo, concernentes ao tráfico de africanos para o Brasil.

Palavras-chave: tráfico de escravos; legislação; prescrições; higiene; doenças.

\section{Abstract}

In 1808, Dom João VI issued an edict which regulated the shipping and treatment of slaves on the transatlantic crossing from Africa. Two years later, Antonio de Saldanha da Gama, a member of the Treasury Council, drafted a letter discussing some points of the resolution. This key figure in the Portuguese administration of Brazil argued that his respectful considerations concerning the determinations of His Royal Highness were designed to improve them "for humanitarian and economic reasons." Safeguarded in the archives of Arquivo Histórico Ultramarino, this letter is transcribed, annotated, and contextualized here, supplying an interesting perspective on the prevailing concerns and justifications about the trafficking of African slaves to Brazil.

Keywords: slave trade; legislation; prescriptions; hygiene; diseases. 
$\mathrm{E}^{\mathrm{m}}$ 24 de setembro de 1810, Antonio de Saldanha da Gama, o conde de Porto Santo, tomou a pena para escrever ao conde das Galveias e secretário de Estado da Marinha e Ultramar, dom João de Almeida de Melo e Castro, sobre uma matéria recorrente nas correspondências e na legislação de então: as condições de captura, transporte e venda dos africanos escravizados, ou, em poucas palavras, o tráfico negreiro. Sua manifestação foi motivada pela divulgação de um alvará com força de lei, dois anos antes, pelo príncipe regente dom João VI, que observava

com grande mágoa do meu [seu] paternal coração, o lastimoso estado em que chega[va] aos portos deste Continente uma grande parte dos escravos resgatados nos meus [seus] domínios, Ilhas, Presídios e Territórios adjacentes à Costa de África, que escapam à horrível mortandade de seu transporte (Alvará..., posterior a 24 set. 1808).

Não era, contudo, pela ausência de um regulamento que Sua Majestade teve de se debruçar sobre esse assunto. Desde 1684, vigorava uma lei voltada para a regulação da arqueação dos navios, ou seja, de que maneira sua tonelagem ou carga deveria ser medida ou regulada, na qual o transporte dos escravizados tinha destaque. Observemos mais de perto os percursos trilhados por essa legislação sobre o "infame comércio" (Rodrigues, 2000), notadamente suas prescrições para o trato dos africanos - grosso modo, sua alimentação, saúde e vestimenta - nos caminhos do Atlântico, e as justificações anunciadas para que determinadas ações fossem levadas a cabo.

\section{Sobre a Lei das Arqueações de 1684}

A lei que ficou conhecida a posteriori como Lei das Arqueações, datada de 18 de março de 1684, versava, em linhas gerais, sobre a "condução dos negros cativos de Angola" (Registo..., 1948, p.379). Esse regulamento pode ser entendido em grande medida como uma resposta a cartas e solicitações que se multiplicavam em anos anteriores, preocupadas com as condições dos navios, com a tripulação e, sobretudo, com os reveses financeiros faceados por negociantes de lá e de cá. Tal legislação, nesse sentido, procurou sistematizar soluções para o amontoado de contendas e determinar um padrão de ação nos portos que enviavam e recebiam as cargas humanas, de modo geral: como deveria ser escolhida e composta a tripulação? Religiosos deveriam ir embarcados - e, se sim, quem? Quais as escalas físicas mínimas e máximas requeridas para embarcações? De onde deveriam advir os materiais componentes da estrutura do navio? Quantos escravos poderiam ser transportados? E de que modo? Que instruções e trato deveriam receber ao longo do caminho? De que víveres e em que quantidades o navio precisaria estar abastecido?

Sobre a presença de membros da Santa Sé nas galeras, por exemplo, são encontrados, ainda em 1623, justificações e apelos para se ter um capelão a bordo. Em uma carta de religiosos em missão na África, há a solicitação de que obrigatoriamente houvesse, nos negreiros oriundos de Guiné, Angola, Cabo Verde e São Tomé, a presença de sacerdotes responsáveis pela doutrinação ao longo do translado (Alvará..., 7 out. 1623). Em repetidas ocasiões, ainda, a necessidade de se batizarem os escravizados fora reportada, e o prevalecimento de uma ordem para as missões foi destacada, a exemplo da correspondência do frei Fortunato, que informava, em 1679, a ineficiência da pregação dos capuchinhos e sua incapacidade em colher almas negras por 
meio do batismo: para ele, esses religiosos eram ignorantes e apenas os jesuítas especialmente preparados para tal deveriam compor as frotas (Silva, 1856, p.110-117).

A própria estrutura do navio era contemplada nessas missivas e reclamações, o que levou a Coroa portuguesa a determinar que todo o ferro utilizado nas carcaças deveria portar o selo real, a fim de evitar qualquer tentativa de alteração nos pesos das estruturas. A princípio, aferir a chamada "arqueação" de uma embarcação pressupunha calcular quantos tonéis poderiam ser acomodados em seu interior (Leitão, Lopes, 1974, p.58), ou seja, realizar a "medição do volume interno dos espaços permanentemente fechados do navio, como base para a sua utilização comercial e, em especial, para a aplicação de direitos" (Esparteiro, 2001, p.543). Até finais do Seiscentos, especialmente, a medição desses espaços era feita de modo bastante empírico, com arcos de ferro que norteavam as conferências empreendidas pelos funcionários régios, dando informações sobre sua tonelagem e capacidade de transporte de cargas de toda a sorte.

É sabido, aliás, que antes de transportar negros cativos as embarcações portavam bens europeus para troca e, depois de aportar na América, retornavam repletas de produtos coloniais, como a madeira, o açúcar e o tabaco, todos fonte de altas receitas aos cofres portugueses (Mauro, 1997, p.229). Mesmo com certa alteração do modelo de comércio marítimo - do chamado "triangular", entre Portugal, África e Brasil, para um tipo direto que não envolvia a metrópole (Alencastro, 2000, p.118) -, era com base nessa arqueação ou tonelagem que alguns impostos eram cobrados e calculada a quantidade de produtos a ser comercializada e transportada; quer dizer, se algum navegador ou comerciante quisesse burlar o esquema de pagamento de taxas, a fraude ocorreria na arqueação. Em poucas palavras, ao exigir que todo o ferro proviesse da Coroa, as tentativas de sonegação de direitos sobre as cargas eram cerceadas. O uso dessa técnica parece ter sido paulatinamente substituído por outros critérios de contagem ao longo do século XVIII, notadamente com a consideração da distância que seria percorrida e o tipo de carga transportada (Domingues, 2000, p.535). Contudo, para a feitura dessa legislação setecentista, aquele conhecimento prático e respaldado pelos arcos selados pelo poder régio era a regra.

Vale destacar que, levando em conta os critérios indicados pela "Lei das Arqueações", diversas embarcações de fabrico no Brasil passaram a ser utilizadas para o comércio de almas. Navios mais ágeis, de médio porte - que fossem capazes de comportar muitos cativos e, ao mesmo tempo, não tomassem demasiado tempo para manobra nos portos africanos -, com linhas esguias e, ainda, levemente arredondados para abrigar a quantidade permitida (ou desejada?) de escravos, rum e aguadas ${ }^{1}$ necessárias (Miller, 1988, p.367), eram os escolhidos: charruas, caravelas, paquetes, corvetas, galeões e briques configuravam a primeira opção, apesar de as galeras, os navios e as naus, mais amplos, serem também utilizados. Como as embarcações, em geral, não se destinavam a carregar exclusivamente escravos (Mauro, 1997, p.229), mas variados produtos de interesse metropolitano - embora esse ramo de comércio tenha tomado cada vez mais corpo e importância para lusos e brasileiros ao longo do período colonial -, cuidar de perto de sua arqueação tornou-se fundamental.

Entre os tópicos recorrentes nessas missivas, a carestia de água a bordo parece ter recebido especial atenção da Coroa. É o que se vê, por exemplo, em 1664, na fala de El-Rei ao seu braço de governo em uma das porções africanas de saída de navios; ele ordena: 
Eis por bem que mando ao meu governador do dito Reino de Angola, e ao Provedor de minha Fazenda dele, [que] façam ter particular cuidado e vigilância no despacho dos ditos navios, para que nenhum possa sair do porto da Cidade de São Paulo sem levar para cem peças ${ }^{2}$ vinte e cinco pipas de água, bem acondicionadas, e arqueadas (Provisão..., 6 nov. 1664).

Essa ordem de Afonso VI, então rei de Portugal, parece ter sido uma tentativa de responder a outras cartas recebidas pelo Conselho Ultramarino, que tratavam não somente, como se viu, do abastecimento dos navios, mas ainda do excesso de africanos embarcados e do elevado índice de mortes, ocasionado, também, por essa superlotação. Em uma delas (Sobre..., 19 dez. 1643), consta a reclamação, por parte de alguns carregadores, do constante aumento no número de cativos que saíam do porto de Luanda. Nela, além de confirmarem que a quantidade de africanos mortos durante a travessia só fazia crescer, revelam a ausência de uma vistoria rigorosa da quantidade de alimentos e água portados pelos negreiros. A população pede a solução urgente de tal ponto, sugerindo a nomeação de homens de sua confiança para a fiscalização dos navios antes de seguirem viagem.

Contudo, será apenas com a legislação que passa a vigorar em 1684, a primeira que contemplava todo o Império Ultramarino, ${ }^{3}$ já sob os auspícios de dom Pedro II, que a questão da quantidade de peças e alimentos passa a ser efetivamente contemplada. O soberano revela ter sido informado de

que, na condução dos negros cativos do Reino de Angola para o Estado do Brasil, obram os carregadores e mestres das naus da violência de os trazerem tão apertados e vindos uns com os outros que semelhantes falta o desafogo necessário para a vida, cuja conservação é comum e natural para todos ou sejam livres ou escravos, mas do aperto com que vêm sucede maltratarem-se de maneira que, morrendo muitos, chegam infalivelmente lastimosos os que ficam vivos (Registo..., 1948, p.380).

Com o intuito de resolver essa calamitosa situação, o rei ordenara que tal matéria fosse apreciada por "pessoas de toda a satisfação, doutas, práticas e inteligentes nela" e que, assim, se produzisse um regulamento para, em suas palavras, "prover de remédio a tão grande dano" (Registo..., 1948, p.380). A preocupação do monarca parece ser bastante justificável, haja vista a constatação ${ }^{4}$ de que a mortalidade nos negreiros - e aqui fica patente a alcunha de "tumbeiros" que receberam - tinha o maior índice entre qualquer das viagens de longa distância daqueles tempos (Klein et al., 2001, p.114).

O regulamento era composto por 25 incisos, entre deliberações sobre as medições, as posturas, o pessoal, os provimentos e, ainda, as penas para os que as descumprissem. Das determinações do soberano para certa racionalização e sistematização dos procedimentos considerados então acertados para o tráfico e comércio, destaca-se, de saída, a restrição aos encarregados de realizar a arqueação: na capital portuguesa, estariam autorizados apenas ministros e oficiais, especificados em decreto do Conselho Ultramarino; no Porto, o superintendente da Ribeira do Douro ou o juiz da Alfândega; no Brasil, o provedor da Fazenda ou seus procuradores, baseados na Bahia; em África, por fim, ministros e oficiais, ainda que as embarcações já tivessem passado pela arqueação em seu porto de origem. A medição da arqueação levava em conta espaços cobertos e descobertos da embarcação, partes superiores e inferiores, com e sem portinholas, quantos adultos e quantas crianças se queriam transportar; 
ou seja, as aferições eram realizadas parte a parte e dependiam de todas as variantes e detalhes de cada um dos pequenos, médios ou grandes barcos. Por isso, como sublinha a lei, apenas funcionários especializados e experientes poderiam fazê-la a contento.

Para se ter uma ideia de quantos escravos poderiam ser embarcados, já que a relação entre a arqueação e o número de cativos era indissolúvel, tomemos por base um navio de oitenta toneladas (Caldeira, 2013, p.117): ali, a capacidade variava de trezentos a quatrocentos sujeitados. Nesse cálculo - expressa-se obrigatório na lei - deveriam constar também o peso e o espaço ocupados pelos víveres necessários para a manutenção dos escravizados e tripulação ao longo do trajeto Atlântico. Lê-se ser imperativo "os ditos navios e embarcações levarem os mantimentos necessários para darem de comer aos ditos negros três vezes ao dia, e a fazer e levar água que abunde para lhes darem de beber em cada um dia uma canada, infalivelmente" (Registo..., 1948, p.382). Para tanto, completa a regra, "se arquearão e medirão igualmente os porões fazendo-se estimação dos mantimentos e aguadas que podem receber", considerando o número de dias de viagem e o destino: "de Angola para Pernambuco trinta e cinco dias de viagem, para a Bahia quarenta, e para o Rio de Janeiro cinquenta, além dos mantimentos e aguada que for necessária para a gente dos navios" (p.382). Essa contagem deveria contemplar também os embarques, somando-se "dez dias mais nos mais portos donde se carregarem negros a respeito do tempo que costuma ser necessário para os portos a que forem carregados" (p.382).

A citada legislação regulamenta, ainda, que qualquer escravo, quando adoentado, deveria ser tratado "com toda a caridade e amor de próximos" (Registo..., 1948, p.382). Para tanto, deveriam ser "levados e separados para aquela parte onde se lhes possam aplicar os remédios necessários para a vida" (p.382), de modo a receberem um tratamento físico apropriado. Os aspectos espirituais não eram olvidados: a "lei das arqueações" determinava ser obrigatório que todos os navios levassem um sacerdote que, além de servir "de capelão para neles dizer missa ao menos nos dias santos", tinha como função "assistir aos moribundos" (p.383).

Ciente da resistência que esse regulamento poderia sofrer, principalmente por parte de traficantes - já que a garantia de melhores condições no navio, como menor carga e maiores gastos com alimentação e saúde, encarecia o frete e, consequentemente, reduzia os lucros -, o monarca tratou de elencar uma série de punições para aqueles que tentassem burlá-lo. Atentou-se em primeiro lugar para os responsáveis pela arqueação, que poderiam receber propostas de propina ou, por desleixo, pouco se atentassem à regra. Ele diz:

Ordeno e mando que o provedor-mor da Bahia e os mais provedores da Fazenda que por culpa, negligência ou omissão deixarem carregar ou permitirem que se carreguem mais negros daqueles que forem lotados aos navios por suas arqueações, ou que consentirem que as ditas arqueações se façam em outra forma da que é disposta nesta lei incorram em perdimento de seus ofícios em a pena do dobro do valor dos negros que de mais forem carregados e em seis anos de degredo para o Estado da Índia. Que os patrões-maiores e mestres da Ribeira percam os seus ofícios e sejam degredados dez anos para o mesmo Estado da Índia, e que todos com suas culpas formadas sejam remetidos presos para esta corte para nela serem sentenciados como também as mais pessoas que assistirem as ditas arqueações havendo-se com dolo e cometendo nelas erros de culpa notória (Registo..., 1948, p.385). 
Perda do cargo, pagamento de multas substanciais e degredo: as consequências em caso de prática ou testemunho de uma arqueação imprópria mostram-se bastante duras. E isso para os mais altos cargos. A legislação informa pormenorizadamente, nos parágrafos seguintes (do 18 ao 24), que "toda esta disposição não poderá ter a execução ordenada se os ministros [e outros funcionários nomeados, dependendo da localidade] aos quais pertence o cuidado dela o não tiverem muito vigilante em a cumprir", indicando as penas "de maior severidade" para quem não guardasse as ordem do rei e persistissem em "cometer os abomináveis erros que até agora se usavam ou que ordinariamente aconteciam" (Registo..., 1948, p.385). Ele encarregava e encomendava, particularmente aos governadores, "a exação e execução e cumprimento desta lei" (p.386), em tom incisivo e intimidador:

espero se hajam na observância dela com tal cuidado que tenha muito que lhes agradecer porque do contrário me haverei por mal servido deles, e quando a encontrarem em algum caso, ou de alguma e qualquer maneira mandarei proceder contra eles como desobedientes às minhas ordens.

Em poucas palavras, a lei das arqueações de 1684 pode ser entendida como um "marco regulador do comércio negreiro - também em benefício da vida dos escravos durante a viagem da África para outros portos e do aumento da quantidade dos que chegariam vivos e com saúde" (Cavalcanti, 2005, p.19). Sua eficiência e observação, apesar disso, podem ser contestadas. Embora existam referências de sua implementação - como em Pernambuco, já em 1685, em uma missiva do ouvidor-geral da capitania, solicitando os arcos necessários para arquear os navios conforme a lei (Vareiro..., 17 ago. 1685), ou as notícias do governador e capitão-general do estado do Maranhão e Pará, João de Abreu Castelo Branco, em 9 de novembro de 1744, sobre as medidas por ele tomadas para o cumprimento da regra -, muitas são as ressalvas colhidas dos relatos da época, indicando que a legislação sobre as arqueações encontrava, sobretudo, resistência. É o que se pode ver, por exemplo, em uma correspondência enviada pelo governador do Rio de Janeiro e Minas Gerais, Gomes Freire de Andrade, em 1745, ao rei dom João V, em que comunicava as ordens dadas ao provedor da Fazenda Real (Francisco Cordovil de Sequeira e Melo) de levar a cabo a citada lei e de averiguar as suspeitas de corrupção praticadas pelos capitães dos navios negreiros (Andrade..., 1 jan. 1745); ou ainda, já nos anos finais do Setecentos, nas declarações de Luís Antônio de Oliveira Mendes, em 1793, as quais diziam que "dela se abusava inteiramente" (Pimentel, 1999, p.17). A necessidade anunciada e reiterada em 1808 de se obedecer, ao fim e ao cabo, à legislação já vigente complementa os indícios de que a norma não era de todo atendida.

\section{Dom João VI e as arqueações}

No primeiro decênio do século XIX, outro - mas, talvez, não tão "novo"- regulamento sobre o transporte de escravos desde a África é elaborado e começa a tramitar no Conselho Ultramarino: trata-se da minuta de um alvará com força de lei, redigido por dom João VI. Assim como seu bisavô brigantino dom Pedro II, o então príncipe regente tinha como proposta "evitar o maior número daqueles e mais inconvenientes, na parte que diz respeito à Arqueação das embarcações, resgate, transporte e venda dos escravos da Costa da África", 
por estar "intimamente persuadido de que a Religião, a Humanidade, e o interesse dos meus [seus] vassalos deste continente clamam altamente pela prática das mencionadas novas providências" (Alvará..., post. 24 set. 1808). No seu entendimento, seriam duas as principais causas para os "muito frequentes e desgraçados insucessos" decorrentes dessa matéria, a saber: "em primeiro lugar, a inobservância das saudáveis providências, ordenadas no Alvará e Regimento de 18 de março de 1684, promulgado pelo Senhor Rei dom Pedro Segundo, de Gloriosa Sabedoria, sobre a arqueação das embarcações e transporte dos cativos" e, em segundo lugar, a atualização necessária do regulamento anterior, por "não serem as providências do mencionado Alvará, como o tempo e a experiência têm mostrado, nem suficientes em todo, nem em parte bem regulados, pois que as recentes descobertas físicas exigem alguma alteração nas antigas e ensinam outras, novas, de um indubitável benefício, e de uma fácil aplicação" (Alvará..., post. 24 set. 1808). ${ }^{5}$

Nesse escopo, a Alteza Real reconhecia e condenava a recorrente inobservância das ordens presentes na já familiar ao leitor "lei das arqueações", julgando que esse descumprimento era devedor do "sórdido e mal-entendido interesse, ignorância, má-fé e egoísmo dos armadores e empregados neste trato", bem como a certo desleixo dos funcionários régios, "em cujo cargo e responsabilidade está a fiscalização do exato e religioso cumprimento das minhas [suas] Reais Ordens" (Alvará..., post. 24 set. 1808). Esses homens, de acordo com as informações por ele divulgadas, não vigiavam

ativa, zelosa e constantemente a conduta de seus subalternos e subdelegados, incumbidos da sua execução, e da diligência de prevenir as fraudes e prevaricações em um objeto de tanta gravidade e consequência; dando infelizmente estes mesmos, quase sempre, o exemplo de desordens, que deveriam impedir e denunciar, para serem punidas (Alvará..., post. 24 set. 1808).

São esses os argumentos de que ele lança mão, aliás, nas primeiras linhas do alvará proposto em 1808.

As motivações anunciadas pelo monarca para a revisão da exposta legislação não estavam dissociadas de circunstâncias políticas mais abrangentes, características daquele período, e das quais ele, por certo, não se eximia. Naqueles anos iniciais do século XIX, a maior das aliadas lusas, a Grã-Bretanha, lançava-se em uma verdadeira "cruzada contra o comércio transatlântico de escravos"; no entanto - e ironicamente -, "não havia nenhuma nação mais profundamente envolvida na exportação, no transporte e na importação de escravos africanos do que Portugal" (Bethell, 2002, p.21). São bastante conhecidos os tratados firmados entre essas duas nações para dirimir impasses relacionados com o comércio de almas (Manchester, 1973), e recorrente a associação entre o fim do tráfico de escravos - e a posterior abolição da escravatura - e as investidas diplomáticas (e náuticas) inglesas (Graham, 1973). E isso não era tudo. No âmbito interno, grupos sociais - a exemplo dos parlamentares, traficantes, população livre e pobre e os próprios escravos - apresentavam demandas múltiplas - e, muitas vezes, antagônicas - acerca da condução dos negreiros para o Brasil. Argumenta-se (Rodrigues, 2000), inclusive, que a pressão britânica explica menos as decisões sobre as alterações na corretagem de africanos que a ação constante desses grupos distintos. As querelas na política luso-brasileira sobre se e como o transporte de cativos deveria ser levado a cabo partiam, pois, de múltiplas direções, e ao regente recém-aportado cabia encontrar saídas para esses assuntos. 
Atento, portanto, a tais aspectos, dom João VI determinava, de saída, que os dispositivos elencados no alvará de 18 de março de 1684 e sublinhados na provisão do Conselho Ultramarino de 20 de janeiro de 1712 e nos alvarás de 11 e 25 de janeiro de 1758 encontravamse endossados pela sua chancela real. Em seguida, apresenta as ditas atualizações a esses dispositivos, ponto a ponto, tendo como premissa e baliza, em todos os recuos e referências, aquele primeiro alvará do Setecentos. Observemos algumas de suas ponderações mais de perto.

A primeira delas diz respeito à quantidade de negros escravizados que poderiam ser transportados em cada embarcação. Sua determinação é reduzir em uma sexta parte o número de peças permitidas, ou seja, reduzir a arqueação do navio, "tanto pelo que toca aos adultos como pelo que pertence às crianças", e apresenta um exemplo para ser tomado como base em qualquer outra medição: "se esta dava lugar para 450 cabeças, de todas as idades, não poderá daqui em diante dar lugar para mais de 375, de iguais cativos" (Alvará..., post. 24 set. 1808). E por prezar não somente que o número autorizado de escravos pudesse transitar, mas também que sua integridade física fosse devidamente cuidada e garantida, ordena expressa e incisivamente "que toda a embarcação, que, em duas viagens interpoladas ou sucessivas, perder a $8^{\text {a }}$ parte, ou mais dos escravos, que tiver embarcado no Porto de Saída, seja condenada, para nunca mais poder servir nesta Navegações e Comércio" (Alvará..., post. 24 set. 1808).

Esse, que é o quinto inciso do alvará, denota claramente que as normas concernentes ao trato do escravo no caminho marítimo deveriam ser mais bem observadas, sob pena de o traficante perder em definitivo a licença comercial de almas. Mais adiante, no $14^{\circ}$ parágrafo, indica, como uma espécie de bonificação aos que seguissem a lei, que "as embarcações que não perderem no seu transporte mais do que dois por cento do número dos cativos durante a sua viagem, e até o momento da visita [do físico ou seus delegados], serão preferidas no bando e carga às outras" (Alvará..., post. 24 set. 1808), preterindo embarcações que tivessem, inclusive, chegado há mais tempo.

Todos os elementos que alargassem as condições salubres (Rediker, 2011) da viagem foram, pois, alvo das reflexões reais: a normativa chegou a proibir, no quarto artigo, que outros produtos fossem incluídos em um mesmo frete carregado de escravos, para que os espaços e esforços necessários para a manutenção dos corpos não fossem desviados. Não seria equivocado afirmar que, no centro de suas preocupações, estava justamente a de ajustar e regrar os suprimentos necessários ao translado, pois que a carestia de alimentos, água ou medicamentos no caminho atlântico configurava como principal causa de transtornos e mortes. Nesse sentido, dom João VI indica que todas as caldeiras deveriam ser confeccionadas em ferro e reconhece que a "qualidade do abastecimento e de aguada e a quantidade desta" eram "um dos objetos mais eficientes para a saúde dos passageiros e tripulações", razão pela qual deveria haver "o maior cuidado no exame destes gêneros e vasilhas" (Alvará..., post. 24 set. 1808). Ele estipula, com rigor, a quantidade de água mínima necessária para pôr uma galera em viagem - e que era superior e mais bem delimitada que a outrora determinada em 1684:

será calculada a 8 libras de águas por dia para cada Indivíduo, ou cabeça, entrando os cativos e tripulações, reputada a viagem de 60 dias, a de Angola para este Porto [do Rio de Janeiro]; o que vem a fazer 25 tonéis por cada Pessoa, sendo o tonel de 2 pipas, a pipa de 180 medidas, e a medida de 6 libras de fuso, com pouca diferença; servindo esta regra de norma para o cálculo de Aguada para as outras viagens dos diferentes Portos 
de Saída e de volta; alterado na sobredita proporção o Capítulo $8^{\circ}$ do já citado alvará. Cada embarcação terá um lugar separado com divisão de Madeira destinada para a enfermaria dos cativos [separada do local de guarda da água e dos mantimentos] que adoecerem (Alvará..., post. 24 set. 1808).

Complementarmente, ele pôs em papel e tinta os víveres essenciais para abastecer a botica do navio - uma pipa de vinagre para as fumigações, uma pipa de mel e um desinfetador de M. Morveau ${ }^{6}$-, todos eles empregados de acordo com as instruções do físico-mor do reino. Aliás, estava entre as atribuições desses profissionais indicar a constituição, o uso e os ingredientes para o preparo das drogas necessárias aos embarcados e a maneira de se servir de ventiladores, dados como "indispensáveis nestas conduções", além de regular todo o tratamento dos cativos durante a viagem e a qualidade dos alimentos para o seu sustento diário (Alvará..., post. 24 set. 1808).

O físico-mor (Abreu, 1900; Edler, 2006; Marques, 1999; Soares, 2001) firma-se, nesse contexto, como uma peça-chave para a conservação da saúde, ficando responsável pela observação dos corpos dos cativos em todo o trajeto, desde os portos de embarque até o local de destino daquela carga humana. É interessante notar que, em relação ao alvará de 1684, seria esse dos mais significativos deslocamentos: enquanto nas ordens de dom Pedro II a figura do religioso era elencada como obrigatória para a execução da viagem, dom João VI direcionará seus esforços para sublinhar a importância de uma figura ligada à medicina para o translado. A necessidade de um padre, embora possa ser considerada uma das matérias inalteradas do documento anterior, não recebe qualquer destaque na fala do então príncipe regente.

As indicações ditas "científicas" (Pimenta, 2003) passariam a ser consideradas, notadamente as que se relacionam com a prevenção de doenças contagiosas, como se vê, por exemplo, na ordem de se criarem, "em todos os portos deste Continente onde é permitida a descarga destas embarcações", um lazareto em separado da cidade, "em lugar arejado e cômodo, no qual possam facilmente embarcar os escravos, e ficar depositados e sustentados por teus respectivos donos com uma consignação diária", conservando-se ali "até que o Juiz Comissário Delegado do Físico-Mor do Reino, que será também Médico da Saúde, e que terá a seu cargo o fazer repetidas visitas, segundo a urgência, os julgue individualmente em estado de poderem sem inconveniente de contágio sair para casa de seus donos" (Alvará..., post. 24 set. 1808). Além de avaliar se o escravo podia seguir para o domínio de seu senhor, os físicos e seus delegados eram responsáveis por contabilizar os mortos e adoentados no momento da chegada da embarcação, dado fundamental para a aplicação daquelas penas ou bônus outrora citados, e emitir certidões juramentadas sobre essa matéria.

Ainda sobre a vigilância das doenças, ficava ordenado, pelo exposto alvará, que nenhum cativo oriundo de Angola, Benguela, Cabo Verde ou São Tomé e Príncipe poderia embarcar paras as terras americanas se ficasse constatado que padecia de alguma moléstia contagiosa, nem mesmo se não houvesse manifestado "bexigas, ou naturais ou provocadas por meio de inoculação ou da vacina" (Alvará..., post. 24 set. 1808). Àquela época, sobre as bexigas (Rosen, 1994), ou, como hoje conhecemos, a varíola, já era sabido que se a vida do doente não fosse ceifada após o aparecimento de pústulas, altas febres, dores, fatiga e até a cegueira, o que era muito comum, ele se tornaria imune a outras ocorrências em definitivo. Por esse motivo, a inoculação de uma pequena quantidade de substância presente nas bexigas era uma forma 
corrente de "vacinação" - o regente de Portugal e do Brasil reiterava suas ordens, nesse mesmo inciso, de que o pus vaccinico fosse transportado da Bahia para Angola e, na ausência desse, que se procedesse ao uso do pus presente nas bexigas naturais - e a única certeza de que uma epidemia em alto-mar seria evitada era o transporte unicamente de escravos já remediados.

A presença de um cirurgião licenciado e aprovado (Pimenta, 1997) passaria a ser obrigatória pelo $15^{\circ}$ artigo do disposto Alvará, "para cuidar dos escravos enfermos". Na ocorrência excepcional de o armador do navio não encontrar um profissional que pudesse ou quisesse realizar tal trabalho, alguém de confiança e saber deveria ser instruído a realizar tal tarefa, especialmente distribuir as curas, quando necessário. A escolha dos marinheiros para este fim só poderia ser realizada, segundo a Alteza Real, por um ministro. Em suas palavras, os encarregados dessa essencial tarefa deveriam saber sangrar e seguir

o uso prático das instruções dadas, como já determinei, pelo físico-mor, tanto a respeito do tratamento dos escravos, como sobre a aplicação dos remédios; e execução das providências mandadas observar relativamente às fumigações, uso do desinfetador, ventilações, e mais diligências, para conservar sempre as cobertas limpas, e o seu ar puro e vital (Alvará..., post. 24 set. 1808).

A fim de que se fizessem sabidas e, sobretudo, cumpridas, essas ordens da Alteza Real foram replicadas em diversos outros documentos, haja vista as notas, anotações, bilhetes, lembretes, informações, ofícios, provisões e portarias que se encontram anexados ao manuscrito em discussão e que perfazem um total de 54 laudas. Não é possível aclarar, contudo, como esse processo de divulgação se deu, ou elencar mais precisamente quem apreciou essa minuta de alvará, dado que ele não será imediatamente publicado com força de lei. É provável que tenha circulado entre o alto escalão administrativo, havendo quem se manifestasse para complementar ou sugerir algumas modificações nesse novo intento de regular a arqueação dos navios e o tráfico negreiro. É o caso, como veremos, de Antonio de Saldanha da Gama, em 1810.

\section{O olhar de Gama sobre o tráfico}

O conde de Porto Santo, dois anos depois da escritura dessa minuta de alvará de dom João VI, decide reportar-se ao (quinto) conde das Galveias, dom Francisco de Almeida de Melo e Castro, sobre alguns aspectos da determinação real. Para ele, muito embora Vossa Alteza tenha acertadamente aparado diversas arestas presentes na norma sobre o tráfico de escravos, algumas ainda poderiam ser aperfeiçoadas. Suas considerações advinham da larga experiência administrativa: aristocrata, militar da Armada, sócio honorário da Academia de Ciências de Lisboa e político, logo em 1806 fora nomeado, como seu pai, para vogal do Conselho Ultramarino; em 1807, passou a atuar como governador-geral de Angola, ${ }^{7}$ até que, após a fixação da Corte portuguesa no Rio de Janeiro, radica-se nessa cidade e integra o Conselho da Fazenda. É nessa função e condição que tece seus apontamentos sobre o tráfico negreiro.

Embora reconheça a importância de se pensar e legislar sobre os negreiros com base em uma perspectiva humanitária, a premissa mais notória em seu ofício é econômica: irá se posicionar contra as restrições de outros produtos no mesmo frete de cargas vivas; indicará os problemas que poderiam ser causados à Fazenda real e privada quando do aumento de custos que incidiam sobre o preço final do escravo; e sublinhará a necessidade da manutenção da 
vida do escravo ao longo do trajeto, para não haver prejuízos aos traficantes, comerciantes ou futuros senhores. Ponto a ponto, o conde comentará as determinações reais, louvando e endossando grande parte delas, como a que trata da presença de um cirurgião a bordo, mas refletindo e cerceando o ônus que poderia ocorrer, no caso de o profissional sobrevalorizar as receitas cobradas por seu trabalho.

Não foi localizada, no universo de correspondências preservadas pelo Conselho Ultramarino em seu arquivo, resposta do rei ao ofício do conde, o que não significa desatenção àquela matéria ou às proposições de Saldanha da Gama. Após um breve hiato sobre o assunto - outrora suscitado pelo próprio dom João VI, em 1808, como visto -, em 24 de novembro de 1813, Sua Alteza Real expediu um alvará especialmente preocupado em regular a arqueação dos navios negreiros. Nesse documento, ele admite que o Brasil contava com menos população que o desejável e necessário para a manutenção e o aumento da agricultura, reiterando a precisão do tráfico de escravos para essas plagas. Sublinha, contudo, que esse não poderia ser movido pela "barbaridade e sórdida avareza de muitos dos mestres das embarcações que os conduzem", por homens "seduzidos pela fatal ambição de adquirir fretes e de fazer maiores ganhos" (Alvará..., 24 nov. 1813). Ele estava ciente do "tratamento duro e inumano" ao qual os africanos estavam submetidos, da falta de "alimentos necessários para a subsistência deles, não só na quantidade, mas até na qualidade, por lhes fornecerem gêneros avariados e corruptos", e afirma que não poderia "encarar sem horror e indignação manifestarem-se enfermidades, que, por falta de curativo e conveniente tratamento, não tardam e fazerem-se epidêmicas e mortais". "Meus constantes e naturais sentimentos de humanidade e beneficência", ele assevera, não podiam mais "tolerar a continuação de tais atos de barbaridade, cometidos com manifesta transgressão dos direitos divino e natural, e régias disposições dos Senhores Reis meus Augustos Progenitores" (Alvará..., 24 nov. 1813). Diante dessas motivações, passa a prescrever algumas providências, divididas em 12 incisos.

Nas tantas determinações presentes nesse dispositivo, as indicações advindas das recentes descobertas científicas, a preocupação com o estado e a qualidade dos alimentos e a salubridade dos locais passam a figurar entre o que deveria ser observado com mais acuidade. Esses tópicos foram sublinhados pelo conde de Porto Santo na mesma direção. Em relação a alguns pontos aventados pelo conde e que deveriam ser revistos pela Alteza Real, especialmente sobre a proibição de se levar, junto aos escravos, outros fretes, ou às caldeiras de ferro, parece que mereceram, de fato, uma reconsideração: esses não constam mais no regulamento da arqueação. Grosso modo, esse alvará com força de lei, esse sim publicado e dado a público, acata muitas das ponderações que o leitor encontrará no ofício aqui transcrito. É importante destacar, ainda, que o intermediário da revisão e divulgação do dispositivo régio é o conde das Galveias, a que se reportou, também, o conde do Porto Santo.

A determinação régia de 1813 faz-se repercutir no Velho Mundo, pelas letras da Gazeta de Lisboa, um jornal de cunho político e publicado (1715-1820) com privilégio de Sua Alteza Real, no ano seguinte. No segundo dia de abril daquele 1814, o periódico informa que,"na corte do Rio de Janeiro, se publicaram dois alvarás de S[ua] A[lteza] R[eal] entre eles "um em data de 14 de novembro de 1813, regulando a arqueação dos navios empregados na condução dos negros, que dos portos de África se exportam para os do Brasil, dando as mais saudáveis e benignas providências em benefício daqueles indivíduos" (Gazeta..., 2 abr. 1814). 
Vale notar que não são todas as ações do rei ou da Corte que mereciam destaque nesse impresso. A amplitude da divulgação da nova normativa dá alguns indícios sobre a necessidade de expor aos europeus - talvez, em especial, aos ingleses - que os assuntos referentes ao tráfico de escravos, sobretudo os mais espinhosos, não passavam despercebidos aos olhos do rei. Indicava, como o quer sublinhar o jornal, que a Coroa se preocupava com a condução do comércio de almas, e que esse só poderia ser praticado dentro de limites precisos.

Os apontamentos de Saldanha da Gama, parte da discussão sobre o aumento da produtividade das fazendas e do melhoramento do trabalho escravo - entenda-se: obter cada vez maior desempenho com menores custos (Davis, 2001; Florentino, 2005, entre outros) -, considerando as demandas por um trato mais "justo" e saudável e esquivando-se das ideias de abolição da escravatura, estão integralmente transcritos a seguir. O documento por ele redigido, originalmente, apresenta-se em 16 páginas manuscritas. Em relação a ele, foram efetuadas pequenas modificações, com o fim último de deixar a leitura mais clara e fluida. Essas alterações, cumpre ressaltar, circunscrevem-se à atualização gráfica dos termos e da pontuação da missiva. Em alguns momentos, palavras foram acrescentadas para corroborar a compreensão da sentença - nesse caso, os acréscimos estão entre colchetes. A organização do texto foi mantida como se apresenta no ofício original, sem que a ordem de parágrafos ou frases fosse alterada. Por fim, algumas notas explicativas foram incluídas ao longo do ofício, de modo a elucidar ao leitor termos particulares de que Antonio de Saldanha da Gama lançou mão.

\section{AGRADECIMENTO}

Este trabalho é resultado de pesquisa desenvolvida no âmbito do projeto temático "Escritos sobre os novos mundos: uma história da construção de valores morais em língua portuguesa", financiado pela Fundação de Amparo à Pesquisa do Estado de São Paulo (processo 2013/14786-6).

\section{NOTAS}

${ }^{1}$ Agôada [aguada] (termo de homens do mar): provisão de água doce para os navios (Bluteau, 1728, v.1, p.175).

${ }^{2}$ Cada "peça" se refere a um escravo.

${ }^{3}$ Para Portugal, por exemplo, é possível encontrar, alguns anos antes, quatro diferentes ordenanças sobre essa matéria, em 1607, 1613, 1613 e 1618 (Domingues, 2012, p.36-37).

${ }^{4}$ Tal assertiva pode ser aferida, de forma detida e pormenorizada, pela análise dos dados disponibilizados na base Slave voyages (http://www.slavevoyages.org/).

${ }^{5}$ As cartas, os alvarás e os ofícios manuscritos, referidos ou citados neste artigo, e que compõem o acervo do Arquivo Histórico Ultramarino, encontram-se digitalizados e disponíveis na Biblioteca Digital Luso Brasileira. Esses documentos foram preservados digitalmente a partir do Projeto Resgate, esforço coletivo de manutenção desse rico patrimônio de correspondências entre Portugal e sua então colônia. Para acessar todo o acervo do projeto, ver: http://bdlb.bn.br/acervo/handle/123456789/67655.

${ }^{6}$ Refere-se ao químico francês Louis-Bernard Guyton de Morveau (1737-1816).

${ }^{7}$ Nessa ocasião, realizou uma importante obra de fomento, deu início ao processo de extração de minério de ferro e cobre na região. Na agricultura, procedeu às culturas de goma copal e de cardamomo. Concedeu isenção aos povos indígenas de alguns tributos e restabeleceu a Aula de Matemática na cidade de Luanda, onde promoveu a construção do primeiro cemitério que ali existiu. Também promoveu, sem sucesso, as primeiras tentativas de travessia do continente africano desde a costa atlântica angolana até Moçambique. É autor da obra Memória sobre as colônias de Portugal, situadas na costa ocidental da África, mandada ao governo em 1814. Como homenagem, a obra foi impressa pelos alunos da Casa Piano no ano da sua morte e depois reeditada em Paris. 


\section{REFERÊNCIAS}

ABREU, Eduardo de.

A fisicatura-mor e o cirurgião-mor dos Exércitos no reino de Portugal e Estados do Brasil. Revista do IHGB, v.63, n.101, p.154-306. 1900.

ALENCASTRO, Luís Filipe.

O trato dos viventes: formação do Brasil no Atlântico Sul, séculos XVI e XVII. São Paulo: Companhia das Letras. 2000.

ALVARÁ...

Alvará com força de lei pelo qual Vossa Alteza Real há por bem regular a arqueação dos navios, empregados na condução dos negros que dos portos de África se exportam para os do Brasil; dando Vossa Alteza Real, por efeito dos seus incomparáveis sentimentos de humanidade e beneficência as mais saudáveis e benignas providências em benefício daqueles indivíduos. In: Coleção de leis do Império do Brasil, v.1, p.48. Disponível em: http://www.camara.leg.br/ Internet/InfDoc/conteudo/Colecoes/Legislacao/ Legimp-C_29.pdf\#page=5. Acesso em: 14 set. 2016. 24 nov. 1813 .

ALVARÁ...

Alvará (minuta) do príncipe regente [D. João], estabelecendo novas providências referente à arqueação das embarcações destinadas ao comércio e transporte de escravos e à sua venda, a fim de se evitar a mortandade dos mesmos. AHU ACL_CU_017, caixa 252, doc.17165/AHU - Rio de Janeiro, caixa 244, doc.48, 49 (Arquivo Histórico Ultramarino, Lisboa). post. 24 set. 1808.

ALVARÁ...

Alvará do Bispo do Congo e Angola. Mesa da Consciência e Ordens, livro 26, fl.130. (Arquivo Nacional da Torre do Tombo, Lisboa). 7 out. 1623.

ANDRADE, Gomes Freire de.

Carta do governador do Rio de Janeiro [e Minas Gerais], Gomes Freire de Andrade, ao rei [dom João V], informando que dera ordens ao provedor da Fazenda Real [do Rio de Janeiro, Francisco Cordovil de Sequeira e Melo], para que observasse a lei das arqueações e mandasse tirar devassas às suspeitas de corrupção praticada pelos capitães dos navios de transporte de escravos do reino de Angola para o Rio de Janeiro. AHU_ACL_CU_017, caixa 37, d.3900/ AHU - Rio de Janeiro, caixa 44, doc.127, 128 (Arquivo Histórico Ultramarino, Lisboa). 1 jan. 1745.

BETHELL, Leslie.

A abolição do comércio de escravos: a Grã-Bretanha, o Brasil e a questão do comércio de escravos, 1807-1869. Brasília: Conselho Editorial do Senado Federal. 2002.
BLUTEAU, Raphael.

Vocabulário português e latino: áulico, anatômico, arquitectônico... Coimbra: Colégio das Artes da Companhia de Jesus. 8v. 1728.

BRANCO, João de Abreu Castelo.

Carta do governador e capitão general do Estado do Maranhão e Pará, João de Abreu Castelo Branco, para o rei dom João $\mathrm{V}$, em resposta à provisão de 15 de maio de 1744 , sobre a lei de arqueação dos navios e outras embarcações negreiras. AHU_ACL_CU_013, caixa 27, doc.2544 (Arquivo Histórico Ultramarino, Lisboa). 9 nov. 1744.

CALDEIRA, Arlindo.

Escravos e traficantes no Império português: o comércio negreiro português no Atlântico durante os séculos XV a XIX. Lisboa: A Esfera dos Livros. 2013.

CAVALCANTI, Nireu Oliveira.

O comércio de escravos novos no Rio Setecentista. in: Florentino, Manolo (Org.). Tráfico, cativeiro e liberdade: Rio de Janeiro, séculos XVII-XIX. Rio de Janeiro: Civilização Brasileira. 2005.

DAVIS, David Brion.

O problema da escravidão na cultura ocidental. Rio de Janeiro: Record. 2001.

DOMINGUES, Francisco Contente (Coord.). História da Marinha Portuguesa: navio, marinheiros e arte de navegar, 1500-1668. Lisboa: Academia da Marinha. 2012.

DOMINGUES, Francisco Contente.

Os navios da expansão: o livro da fábrica das naus de Fernando Oliveira dos séculos XVI e XVII. Tese (Doutorado em História dos Descobrimentos e da Expansão Portuguesa) - Faculdade de Letras, Universidade de Lisboa, Lisboa. 2000.

EDLER, Flavio Coelho.

Boticas e farmácias: uma história ilustrada da farmácia no Brasil. Rio de Janeiro: Casa das Letras. 2006.

ESPARTEIRO, António Marques.

Dicionário ilustrado de marinha. Lisboa: Clássica. 2001.

FLORENTINO, Manolo (Org.).

Tráfico, cativeiro e liberdade: Rio de Janeiro, séculos XVII-XIX. Rio de Janeiro: Civilização Brasileira. 2005.

GAZETA...

Gazeta de Lisboa. Disponível em: http:// repositorio.ul.pt/bitstream/10451/7692/4/ ulsd064500_td_anexos.pdf. Acesso em: 14 set. 2016. 2 abr. 1814. 
GRAHAM, Richard.

Grã-Bretanha e o início da modernização do Brasil. São Paulo: Brasiliense. 1973.

KLEIN, Herbert et al.

Transoceanic mortality: the slave trade in comparative perspective. The William and Mary Quarterly, v.58, n.1, p.93-117. 2001.

LEITÃO, Humberto; LOPES, Vicente. Dicionário de linguagem de marinha antiga e atual. Lisboa: Centro de Estudos Históricos Ultramarinos. 1974.

MANCHESTER, Alan.

Proeminência inglesa no Brasil. São Paulo: Brasiliense. 1973.

MARQUES, Vera Regina Beltrão.

Natureza em boiões: medicinas e boticários no Brasil Setecentista. Campinas: Editora da Unicamp. 1999.

MAURO, Frédéric.

Portugal, o Brasil e o Atlântico, 1570-1670. Lisboa: Estampa. 1997.

MILLER, Joseph.

Way of death: merchant capitalism and the angolan slave trade, 1730-1830. Wisconsin: University of Wisconsin Press. 1988.

OFÍCIO...

Ofício de Antonio de Saldanha da Gama ao conde das Galveias, tecendo considerações acerca das providências a serem tomadas para a melhoria da condução da escravatura da costa de África para os portos do Brasil... AHU_ACL_ CU_017, caixa 259, doc.17749/AHU - Rio de Janeiro, caixa 248, doc.23 (Arquivo Histórico Ultramarino, Lisboa). 24 set. 1810.

PIMENTA, Tânia Salgado.

O exercício das artes de curar no Rio de Janeiro, 18281855. Tese (Doutorado em História) - Universidade Estadual de Campinas, Campinas. 2003.

PIMENTA, Tânia Salgado.

Artes de curar: um estudo a partir dos documentos da fisicatura-mor no Brasil do começo do século XIX. Dissertação (Mestrado em História) Universidade Estadual de Campinas, Campinas. 1997.

PIMENTEL, Maria do Rosário.

Aspectos do quotidiano no transporte de escravos do século XVII: do sertão africano à costa Americana. Estudos Ibero-americanos, v.25, n.2, p.233-244. 1999.

PROVISÃO...

Provisão do Conselho Ultramarino. Cód.92, fl.375v. (Arquivo Histórico Ultramarino, Lisboa). 6 nov. 1664.

REDIKER, Marcus.

O navio negreiro: uma história humana. Trad. Luciano Vieira Machado. São Paulo: Companhia das Letras. 2011.

\section{REGISTO...}

Registo da lei que Sua Majestade manda se guarde neste Estado sobre a condução dos negros cativos de Angola. Documentos Históricos da Biblioteca Nacional, v.79, p.379-388. [7 jan. 1684] 1948.

RODRIGUES, Jaime.

O infame comércio: propostas e experiências no final do tráfico de africanos para o Brasil, 18001850. Campinas: Editora da Unicamp/Centro de Pesquisa em História Social da Cultura. 2000.

\section{ROSEN, George.}

Uma história da saúde pública. São Paulo: Hucitec, Editora da Universidade Estadual Paulista; Rio de Janeiro: Associação Brasileira de Pós-graduação em Saúde Coletiva. 1994.

SILVA, José Justino de Andrade e.

Coleção cronológica da legislação portuguesa.

Lisboa: Imprensa Nacional. 1856.

SOARES, Márcio de Souza.

Médicos e mezinheiros na Corte imperial: uma herança colonial. História, Ciências, SaúdeManguinhos, v.8, n.2, p.407-438. 2001.

SOBRE...

Sobre se navegar em frotas deste reino para o Brasil e daquelas partes para este reino. Consultas mistas, cod.16, fl.127v. (Arquivo Histórico Ultramarino, Lisboa). 19 dez. 1643.

VAREIRO, Dionísio de Ávila.

Carta do [ouvidor da capitania de Pernambuco], Dionísio de Ávila Vareiro, ao rei [dom Pedro II], pedindo que se enviem os arcos para se fazerem as arqueações dos navios negreiros na melhor forma da lei. AHU_CU_015, caixa 13, doc.1340 (Arquivo Histórico Ultramarino, Lisboa). 17 ago. 1685. 
Ofício de Antonio Saldanha da Gama ao conde das Galveias, tecendo

considerações acerca das providências a serem tomadas para a melhoria

da condução da escravatura da costa de África para os portos do Brasil, com 0 menor custo possível, tanto por questões humanitárias, devido à falta de condições de habitabilidade, de higiene e de alimentação existentes nos atuais navios de transporte, de onde resultava a morte de muitos escravos durante a viagem por doença, como por questões econômicas, visto que o aumento excessivo do preço do escravo vendido naquele continente punha em causa a sobrevivência desse comércio com graves prejuízos para a economia no Brasil.

As providências que [a] Sua Alteza Real, o Príncipe Regente Nosso Senhor, pretendo dar para o melhoramento da condução da escravatura da costa da África para os portos do Brasil são dignas de seu paternal coração, e inferindo a humanidade dos habitantes deste continente. Porém, esta matéria não pode ser olhada simplesmente pelo lado da humanidade e precisa atender-se secundariamente a não fazer entrar os escravos por uma porção tão subida ${ }^{1}$ dessa mão de obra que venha a ser escrava, e que prejudique enormemente os interesses da nação. Portanto, me parece [que] devem ser alvo de todas estas providências, o melhor quanto seja possível para a condução da escravatura, aumentando o menos possível as despesas para que isto seja feito, que já se é pesada bastantemente. Aliás, ficará de uma vez perdido este ramo de comércio, ou porque o preço do escravo, por ser constantemente forte, não convida os compradores, ou porque os donos dos navios empregados nesta navegação não tiram dela aquelas vantagens, que possam convidá-los a continuar a sua especulação. Estou persuadido de que sobre esta base se podem alcançar vantagens, uma vez que se atenda ao fim principal e se desprezem as formalidades que só trazem consigo despesas inúteis, e que têm sido continuadas.

O diminuir da Arqueação dos navios é primeiro passo vantajoso a dar-e com efeito, neste ponto, é preciso que cresça alguma despesa ao dono do escravo, para ressarcir o lucro dos navios sobre a perda que vai ter se a diminuição que tiver lugar não exceder a do $\S 2^{\circ}$ do Alvará $^{2}$ projetado. Não julgo dever-se acrescentar alguma coisa ao frete que está em prática, porém somente sancioná-lo, porque a lei não permite frete maior que de seis mil-réis - e [há um] abuso introduzido, a que se tem tolerado debaixo do título de "frete e comedorias", ${ }^{3}$ [e que] sobe [o valor do frete] para doze mil e oitocentos [réis]. Comportando-se as comedorias para este Porto [do Rio de Janeiro], no antigo estado dos mantimentos, a dois mil e oitocentos [réis], pouco mais ou [pouco] menos, fica o frete atualmente tolerado de dez mil-réis por cabeça que chega viva. Este frete parece dar um lucro suficiente ao dono do navio se a diminuição da Arqueação não exceder a sexta parte, não só por ser por uma avultada quantia, mas até porque as providências que se vão pôr em prática, melhorando a sorte do escravo transportado, dão 
mais segurança ao recebimento do frete - que só se verifica chegando ele vivo. Se, porém, o número da Arqueação for mais diminuto do que providencia o Alvará projetado que tenho entre as mãos, deverá aumentar o frete nesta proporção, devendo fixar-se o mais alto preço dele a onze mil-réis, do qual não poderá passar sem que o valor do escravo, e por isso o da mão de obra, cresça notavelmente. Se o número das cabeças da Arqueação se regular pelo número das toneladas do navio - como têm adotado todas as navegações [que] até agora se ocuparam neste tráfico -, deve haver cuidado em evitar o abuso que até agora se tem introduzido, porque sendo a lei a mesma, a Arqueação feita em Benguela é sempre mais diminuída do que a feita em Angola, [e isso] provém de que a medida da tonelada até agora tinha mais de arbitrária do que de exata.

$2^{\circ}$ - Não posso conceber o motivo porque o artigo $4^{\circ}$ do Alvará projetado destrua a possibilidade de que o dono do navio possa carregar de efeitos próprios o seu navio, e por este motivo tenha prioridade de saída, sendo este meio de promover o comércio e abreviar a saída dos navios, e [ao mesmo tempo] o meio que um negociante tem em Angola de fazer embarcar um grande número de escravos, que às vezes lhe chega de repente de seus negociadores do sertão. Aliás, será obrigado a contentar-se com o pequeno número de escravos que os navios do Bando lhe oferecerem pro rata, ficando sustentando por largo tempo o resto da escravatura. E como semelhante prioridade nunca é permitida sem justificação e audiência dos interessados, parece com isso estar evitado todo o dolo de que possa resultar prejuízo de terceiros. A prioridade de saída que era concedida aos navios por virem em direção do Porto de Lisboa me parece dever se abolir.

$3^{\circ}$ - $\mathrm{O}$ artigo $5^{\circ}$ me parece extraordinariamente severo, porque podendo proceder à mortandade da epidemia de bexigas, sarampo, etc. não prova por isso a incapacidade de viagem. Se, porém, a mortandade proceder de defeito intrínseco da embarcação, então nem a segunda viagem se lhe deve consentir, e deverá ser logo condenado depois da primeira, se os defeitos da embarcação forem de qualidade que não possam conhecer à primeira vista; porque então na ocasião da Arqueação se deve condenar.

$4^{\circ}$ - A presença da caldeira de ferro à de cobre é justa, e é de utilidade para os mesmos navios, sendo certo que menos lenha se faz precisa para aquentar a caldeira de ferro do que a de cobre. O vinagre entra sempre da relação dos mantimentos, embarque-se, muito embora o mel de oliva se pode tirar vantagem que corresponda. Porém, não esqueça a aguardente, que, além das utilidades geralmente conhecidas - que provêm da imoderada quantidade das bebidas espirituosas em viagens -, é além disto de suma utilidade aos habitantes da costa da África pela extraordinária paixão que tem por esta bebida, única que lhe pode suprir a falta das que eles usam fermentadas no seu país, e além disso concorre para lhe dissipar a melancolia, origem de grande parte das suas moléstias 
e aflições. Os ventiladores são sobremaneira úteis, mas principalmente nos primeiros dias de viagem, em que o calor da costa da África se faz extremamente sensível aos pretos obrigados a conservarem-se na coberta dos navios. Todas as mais delicadezas que podem de algum modo concorrer para melhorar e purificar o ar são muito úteis, porém difíceis de praticar, e, apesar de serem as circunstâncias bem diferentes, ainda não vi praticar [nenhuma outra medida] a bordo dos navios de guerra, e por isso creio que só poderão influir no preço dos escravos, sem melhorar a sua sorte ou afiançar a sua vida.

$5^{\circ}$ - Mantimentos e aguada são objetos dignos da maior consideração, devendo haver atenção à qualidade dos mantimentos, à quantidade e à bondade deles. [Sobre] a sua qualidade, tem mostrado a experiência que o feijão é o principal alimento da escravatura a bordo dos navios, sem o ser-lhes aborrecidos. [Os escravos] o desprezam absolutamente passados os primeiros dias de viagem, além de que, sendo uma das moléstias que mais perseguem a escravatura a diarreia, [é sabido que] não se faz muito útil tal alimento. Entretanto, como se não pode de todo excluir este gênero, me parece que ao menos uma vez por semana se lhe deve dar arroz com feijão, e se deve misturar ao mais vezes que for possível o milho, gênero que o preto ama excessivamente. Não se deve esquecer o Mandoby, ${ }^{4}$ conhecido em Angola pelo nome de Gingûba: não é crível o contentamento dos pretos quando se lhes distribui este alimento, e por isso me parece dever-se lhes distribuir ao menos duas vezes por semana, entre o jantar e a ceia, ou logo depois da ceia. A carne-seca e o peixe seco, sendo de boa qualidade, são próprios alimentos para a ceia da escravatura, ficando o feijão e o arroz reservados para o jantar. Para alimentar-se, embarcam [víveres] com o destino de servirem de dietas para os que adoecem, e talvez seja preciso sobre tal matéria fazer alguma alteração, dados os conhecimentos das Artes, ${ }^{5}$ devendo ter sempre lugar o fubá ou farinha de milho fermentada, de que os habitantes da África muito se servem para os seus caldos ou Matâtas. ${ }^{6}$

A quantidade dos mantimentos parece-me ser suficientemente arbitrada pelo antigo Alvará das Arqueações, ${ }^{7}$ em relação aos diferentes portos a que os navios se dirigem. É, porém, necessário que se adotem as medidas mais severas para que os mestres dos navios, que, por cobiça ou incúria, ${ }^{8}$ não faltem com o devido alimento à respectiva Arqueação, para cujo fim se devem pôr em prática as vistorias, e devassas estabelecidas pelas ordens antigas, e que hoje estão em desuso.

Em Angola será muito fácil estabelecer uma inspeção que vigie sobre estes artigos sem que se acresça nova despesa, pois que havendo aí uma Junta de Comércio, ultimamente consolidada pela Carta Régia de 30 de janeiro do presente ano, pode esta mesma incumbir-se deste tão importante objeto, nomeandose a cada mês dois dos seus negros comerciantes, que com o seu presidente, o governador e capitão-general, tomam a seu cargo vigiarem sobre a execução das medidas que para este fim forem tomadas. Deveria, contudo, dar-se por 
suspeito o dono do navio que requer mantimentos, se por acaso esse o tiver de mês: os outros, por isso mesmo, que são carregadores do navio, com dobrado interesse vigiarão sobre tal matéria. Em Benguela, poderá o governador [tomar a frente dessa empreita], com dois negociantes, que por turno deveriam fazer essa inspeção, e desta maneira se configura o fim proposto, evitando-se delongas e emolumentos, que o preço dos escravos já não pode admitir.

A quantidade da aguada determinada no Alvará projetado não é excessiva - e talvez mesmo não fosse suficiente, se não fosse quase impossível que os navios gastassem tanto tempo na viagem como o Alvará prefixa para a conta da aguada-, e, desse modo, virá a ficar compensada qualquer falta que ocasionalmente possa haver, ou por se corromper, ou por se perder a água dos tonéis. Deve ser expressamente proibido fazer-se a aguada dos navios em vasos que não sejam para esse fim construídos, com inteira exclusão dos cascos que tenham servido de vinho e aguardente, que sempre corrompem a água, e são além disso muito sujeitos a estragar[em]-se. Sobre o modo de repartir a água, deverá se ter todo o cuidado. Um dos maiores males que o escravo sente na sua passagem, e que talvez seja uma das causas do seu padecer, melancolia, e morte, é a falta da água, não é procedida de ser pouca a quantidade embarcada a bordo dos navios, porém sim do mau método que na maior parte dele se pratica para a distribuição deste gênero tão essencial à conservação da vida do homem. Ser-me-á permitido que eu faça uma pequena descrição do modo com que isto se executa, para que se possam concluir os inconvenientes que dele se seguem. Destina-se um lugar do navio aonde se põem os diferentes vasos, que contêm a água que se há de distribuir este lugar é guardado pelo contramestre e todos os marinheiros do navio armados do chicote de cabo -, a imensa escravatura é posta do outro lado, seguindo-se que um a um venham tornar a sua ração. O preto, por não entender ou [por não] da[r]-lhe [o que] se pretende, ou por queixa [de] sua necessidade, não admite demora [na distribuição dos víveres] e lança-se com ordem e com avidez sobre a água que vê, então serve a pancada de todos os lados: os mais temidos fogem, e também os que se dá sua necessidade com o medo da pancada; o mais ladino afoita-se e toma duas, às vezes mais varões. Ora, devendo toda a Arqueação ser dividida em ranchos de dez pessoas cada um, pelos quais se distribua a comida, sem confusão, da mesma sorte se lhe deve distribuir a bebida, entregando-se a cada rancho a quantidade da água determinada, não havendo meios que eles entre se faltem a exata divisão. O preto, por costume e educação, divide sempre igualmente pelos seus companheiros, tendo quanto tem de comida ou bebida. Não é esta operação tão longa como parece, muito principalmente se os caixotes ou vasos de madeira que se embarcam para a distribuição da água forem feitos e calculados cada um para o número de dez pessoas.

Sobre a situação, extensão e asseio do lugar destinado para a enfermaria dos cativos, se devem adotar todas as medidas expressadas no capítulo $10^{\circ}$ do antigo Alvará das Arqueações, impondo-se, além disso, imediata responsabilidade ao mestre e ao cirurgião do navio, de toda e qualquer falta por mais pequena que 
seja, que a semelhante respeito haja. É certo que a maior parte dos escravos que adoecem, perecem pela falta de trato, inexplicável falta de asseio, e até carência de alimentos. Para que neste objeto haja aquele melhoramento que se deve desejar, é preciso que cada um dos navios tenha ao menos três pessoas que não sejam aplicadas a outro serviço mais [ou além] que ao tratamento dos doentes. Isto, até agora, era unicamente cometido ao Barbeiro do Navio, que supria as faltas do cirurgião, não podendo de forma alguma um homem se acudir e vigiar sobre as precisões de tantos doentes, como os que muitas vezes se ajuntam. Bom seria que todos estes enfermeiros fossem barbeiros aprovados e que tivessem, além disso, os conhecimentos das curas da terra, porém parece-me que no estado atual das coisas não se possa exigir tanto, e que conseguiria melhoramento tendo um deles as qualidades acima ditas, e os outros dois, sendo ladinos e ativos, em poucas viagens se constituirão tão hábeis como o outro. Estes barbeiros ou curandeiros da terra são quanto assim tão necessários, ou ainda mais, que os mesmos cirurgiões, não só porque a moléstia que mais ataca a escravatura é a conhecida debaixo do nome de maculo, ${ }^{9}$ que resiste aos remédios da arte, e cuja cura os naturais do país conhecem com a possível perfeição, mas até porque o preto toma com horror e aversão todos os remédios que lhe são desconhecidos.

$6^{\circ}$ - É muito justo que se proíba embarcar-se escravo algum que padeça de moléstia contagiosa. Não sei, contudo, se esta proibição se poderá estender aos que não tiverem tido bexigas, ou naturais ou provocadas, sem grande detrimento público. Nada digo sobre a vacina, não só porque ainda não existe em Angola - apesar de se ter duas vezes intentado o seu transporte da Bahia, infrutiferamente -, mas até porque a introdução da vacina no Maranhão não correspondeu aos meus desejos e expectação. A inoculação da bexiga se via sobremaneira útil em Angola, e os negociantes que naquela cidade se resolveram a usar deste meio no princípio do corrente ano pouparam as vidas a muitos escravos, ao mesmo tempo que os outros viram morrer em suas casas grande número de escravos, vítimas das bexigas naturais. A experiência destas vantagens há de produzir mais efeitos do que toda e qualquer ordem superior, que devendo se pôr logo em prática, se faz muito sensível pela falta de meio e proporções que cada um para si não tinha ainda adotado. Talvez poderia concorrer muito a promover esta medida diminuir alguma coisa do frete do escravo de que se conhecesse evidentemente ter já tido bexigas - ou naturais ou inoculadas -, porque o dono do escravo procuraria a vantagem do frete, e o dono do navio, tendo mais probabilidade de que aquele escravo chegaria vivo, ganharia maior certeza do frete o que perdia na sua quantidade.

$7^{\circ}$ - Parece-me que pouca ou nenhuma utilidade resultaria da continuação da chamada "cura" que se distribuía pelos marinheiros, não só porque sendo estes poucos - quase sempre se iam empregados nos trabalhos e marinação dos navios, não lhes restando por isso tempo para vigiarem como devem os escravos que 
lhos são confiados -, como também pelas providências que apontei no artigo $5^{\circ}$, se fez inútil maior número de pessoas para o tratamento dos escravos doentes. Ora, o que o dono do escravo vem a poupar neste artigo pode ser aplicado a benefício do dono do navio, cuja despesa vem a ser maior pelo maior número de barbeiros ou curandeiros que no citado artigo anterior, e porque os marinheiros que até agora contavam com estes emolumentos exigirão hoje maior soldada, vendo-se dela privados.

$8^{\circ}$ - As providências apontadas no parágrafo $10^{\circ}$ do projetado Alvará, dirigindo-se à maior clareza e a evitar as fraudes que algumas vezes têm sido feitas pelos mestres dos navios, são de suma utilidade, e deve a sua execução ser vigiada com todo o cuidado. Porém, a humanidade exige que se poupe o mais que for possível ao miserável escravo - as repetidas e cruéis marcas de fogo, que no seu corpo se imprimem, se fosse possível [dever-se-ia] suprir com manilhas ou colares -, e que deste não resultasse falta de tarefa ou prejuízo aos carregadores, poupar-se-ia ao miserável escravo esta ocasião de tormento, que até se lhe repete ao receber o sagrado Batismo.

$9^{\circ}$ - De pertencerem as Arqueações dos navios primitivamente ao porto da saída deste continente, e como manda o artigo $11^{\circ}$ do projetado Alvará, pode resultar inconveniente ao comércio se pelas novas disposições puderem vir os navios comerciar diretamente dos portos da Europa aos da Costa da África, e também embarcações que os habitantes daqueles países comprem aí alguns navios estrangeiros, como várias vezes sucede. Portanto, me parece que [para] tais casos extraordinários haja autoridade nos Portos da África mais habitados, para ali se fazerem as competentes arqueações que, depois, julgando-se necessário, serão ratificadas nos portos do Brasil.

$10^{\circ}$ - Os artigos 12 e 13 sendo relativos ao desembarque e providências da saúde que se pretendem adotar à chegada dos navios da escravatura aos portos do Brasil, pelo seu conteúdo, se fazem alheios das minhas observações.

$11^{\circ}$ - A ideia anunciada no artigo $11^{\circ}$ de conceder vantagens e premiar os navios que mais bem-sucedidos fossem anteriormente no transporte da escravatura produzirá saudáveis efeitos, porém aqui V. Excl. fez a honra de comunicar-me, de premiar primeiramente os mestres e cirurgiões que mais cuidadosos se mostrarem: é mais simples, e menos sujeito às questões que primeira decerto dará lugar.

$12^{\circ}$-É evidentemente conferida a necessidade do cirurgião a bordo dos navios, não só para a cura daquelas enfermidades que são gerais a todos os homens, como para que se evitem as mortes e estragos que causam drogas ativas dadas sem contas, pesos, nem medidas, porém talvez seja preciso pôr termo à ambição dos atuais cirurgiões que pedem somas avultadíssimas por tais viagens, o que 
talvez proceda do pouco número que agora há de homens hábeis para este fim; sendo assim, o tempo irá emendando estes defeitos.

Estas são as reflexões que me ocorreram fazer sobre o projetado Alvará, e como no estado atual da minha saúde me não era possível fazer um discurso seguido sobre este objeto, adotei o método de seguir o plano do mesmo Alvará, e sobre cada um dos seus parágrafos fazer aquelas observações que me pareceram úteis.

Deus guarda a V. Excl.

Rio de Janeiro, 24 de setembro de 1810.

Ilmo. Excl. Sr. Conde das Galveias

Antonio de Saldanha da Gama

\section{NOTAS}

${ }^{1}$ No sentido de elevada.

${ }^{2}$ De 1808.

${ }^{3}$ Ração de víveres, alimentação estipulada para a embarcação.

${ }^{4}$ Amendoim.

${ }^{5}$ Artes de curar, ou medicina.

${ }^{6}$ Esse termo, que não teve sinônimo ou atualização localizada, encontra-se sublinhado e entre aspas no documento.

${ }^{7}$ De 1684.

${ }^{8}$ Omissão, negligência.

${ }^{9} \mathrm{O}$ maculo, mal do sesso, corrupção do bicho ou mal del culo, é o assunto de uma das primeiras obras em vernáculo sobre medicina no Brasil, intitulada Notícia do que é o achaque do bicho, de Miguel Dias Pimenta (1707). Trata-se de uma doença endêmica entre os escravos durante boa parte do período colonial que ocasionava mau cheiro, alargamento e ulcerações anais, podendo chegar, em casos mais graves, à gangrena retal. 